\title{
ВПЛИВ ЕЙМЕРІОСТАТИКІВ НА БІОХІМІЧНІ ТА ІМУНОЛОГІЧНІ ПОКАЗНИКИ СИРОВАТКИ КРОВІ ТЕЛЯТ ЗА ЗМІШАНОГО ПЕРЕБІГУ КРИПТОСПОРИДІОЗУ ТА ЕЙМЕРІОЗУ
}

\author{
B. В. Скальчук ${ }^{1}$, аспірант ${ }^{7}$, \\ М. В. Богач ${ }^{2}$, -р вет. наук, професор, \\ I. В. Пивоварова ${ }^{1}$, канд. вет. наук, асистент \\ ${ }^{1}$ Одеський державний аграрний університет \\ вул. Пантелеймонівська, 13, м. Одеса 65039, Україна \\ ${ }^{2}$ Одеська дослідна станція ННЦ «ІЕКВМ» \\ пр-кт Свободи, 2, м. Одеса, 65037, Україна
}

У статті наведені дані щодо впливу еймеріостатиків на біохімічні та імунологічні показники сироватки крові телят за змішаного перебігу криптоспоридіозу та еймеріозу. Встановлено, щзо в сироватці крові телят на 14 добу після застосування бровітакокциду $i$ ампролеву-плюс збільшився вміст альбумінів на 4,8\% та 15,7 \% відповідно, тоді як глобуліни зменшилися на 2,4\% та 7,7\%.

Відновлення вмісту загального білку, альбумінів $i$ глобулінів, щз стало основою формування А/Г коефічієнту було відмічено вже на 14 добу після задавання ампролев-плюс, а протягом всього експерименту спостерігалася тендениія до зменшення активності ферментів АлАТ і АсАТ та концентрації ииркулюючих імунних комплексів, серомукоїдів, щзо свідчить про незначну, у порівнянні з бровітакокцидом, імуносупресивну дію препарату.

Ключові слова: КРИПТОСПОРИДІОЗ, ЕЙМЕРІОЗ, ТЕЛЯТА, БІОХІМІЧНІ ПОКАЗНИКИ СИРОВАТКИ КРОВІ.

Паразитоценози характеризуються присутністю в макроорганізмі декількох паразитуючих агентів різних таксономічних груп і можуть зумовлювати виникнення асоціативних хвороб [1]. Криптоспоридії часто паразитують сумісно 3 еймеріями та гельмінтами, що призводить до ускладнення лікувально-оздоровчих заходів і підвищення рівня загибелі молодняку тварин [2].

Невизначеною залишається схема застосування тваринам лікувальних препаратів, що мали б високу ефективність.

Ефективним методом лікування телят за криптоспоридіозу є застосування препарату толтарокс з імунобактерином-D, за якого екстенсефективність та інтенсефективність на 28 добу досліджень становили 100 \% [3]. За еймеріозу телят найбільш ефективним виявився препарат байкокс 5 \% у дозі 10 мл/33 кг; екстенсефективність становила 100 \% [4].

Ефективної схеми лікування телят за змішаного перебігу криптоспоридіозу та еймеріозу не запропоновано.

Розроблено лікарський засіб «Ампролев-плюс» екстенсефективність якого за криптоспоридіозу склала $100 \%$, а за еймеріозу 95,7 \% i відповідно показники інтенсефективності становили за криптоспоридіозу $100 \%$, а за еймеріозу 92,9 \% [5, 6].

Згідно $з$ класифікацією хімічних речовин, препарат «Ампролев-плюс» за ступенем небезпечності (ГОСТ 12.1.007-76) відповідає третьому класу небезпечності, відповідно до

${ }^{7}$ Науковий керівник - М. В. Богач, доктор вет. наук, професор 
класифікації речовин за токсичністю - IV класу і ступеню токсичності - «помірно токсичні речовини» [7].

Тому актуальним питанням залишається з'ясування впливу еймеріостатиків на біохімічні та імунологічні показники сироватки крові телят за змішаного перебігу криптоспоридіозу і еймеріозу.

Матеріали і методи. В господарстві ДП ЕБ «Дачна» СГІ-НЦНС Біляївського району Одеської області, неблагополучного щодо еймеріозу та криптоспоридіозу було сформовано три групи телят по 5 голів у кожній.

Тваринам першої дослідної групи задавали бровітакокцид (ТОВ «Бровафарма») перорально в суміші 3 водою у дозі 1,5 г/10 кг маси тіла протягом 5 днів двома курсами 3 інтервалом 5 днів. Телятам другої дослідної групи задавали засіб «Ампролев-плюс» (патент України на корисну модель № 119843) перорально у дозі 1,0 г/10 кг маси тіла протягом 5 днів також двома курсами 3 інтервалом 5 днів. Телята третьої групи слугували контролем. Тваринам контрольної групи задавали ізотонічний розчин натрію хлориду у дозі 3 мл/10 кг маси тіла, одноразово. Кров для досліджень відбирали у телят вранці до годівлі з яремної вени із дотримання правил асептики та антисептики.

Біохімічні показники сироватки крові телят, що відображають функціональний стан печінки, визначали за допомогою автоматичного біохімічного аналізатора IDEXX VestTest («IDEXX Laboratories», США). Додатково у лабораторії біохімії ННЦ «ІЕКВМ» проводили дослідження проб крові на вміст циркулюючих імунних комплексів (за методом Гриневича Ю. А. та Алфьорова А. Н., 1981) та серомукоїдів (за Weimer H. E., Moshin R. J., 1952). У сироватці крові досліджували: активність аспартат-амінотрансферази (АсАТ) та аланін-амінотрансферази (АлАТ) - за методом Райтмана й Френкеля в модифікації К. Г. Калетанакі [8].

Дослідження на тваринах проводили з урахуванням «Загальних етичних принципів експериментів на тваринах», схвалених на Національному конгресі з біоетики (м. Київ, 2001) та узгоджених $з$ положеннями «Європейської конвенції про захист хребетних тварин», які використовуються для експериментальних та інших наукових цілей (м. Страсбург, 1985).

Результати й обговорення. 3 перебігом криптоспоридіозу і еймеріозу у телят 35добового віку як в контролі, так і в дослідних групах до застосування препаратів спостерігали зміни біохімічних та імунологічних показників сироватки крові (табл. 1).

На 3 добу після застосування бровітакокциду та ампролеву-плюс вірогідно $(\mathrm{p}<0,05)$ зменшився вміст загального білку на 0,9 та 0,7 \%, відповідно, порівняно 3 показниками контрольної групи.

В першій дослідній групі на 14 добу вміст загального білку зріс на 0,8 \% і склав

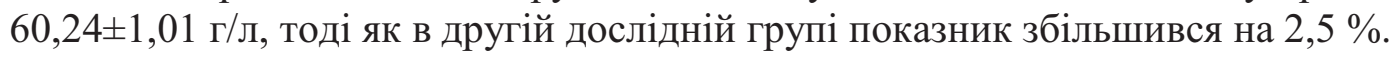

Слід зазначити, що в першій і другій дослідній групі на 3 добу після застосування препаратів знизився вміст альбумінів на 5,1\% та 7,1 \% відповідно. У другій дослідній групі

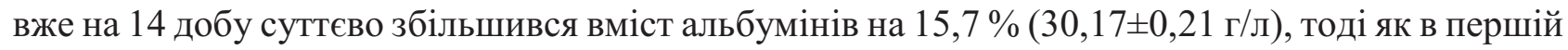

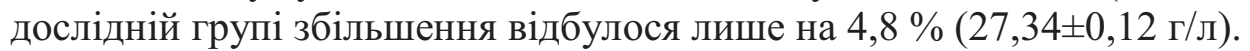

За змішаного перебігу криптоспоридіозу і еймеріозу вміст загальних глобулінів в

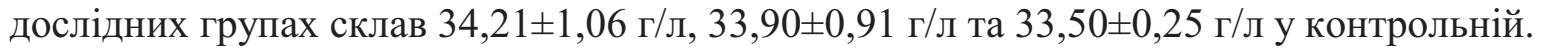

Після застосування бровітакокциду на 3 добу досліду загальні глобуліни були на досить

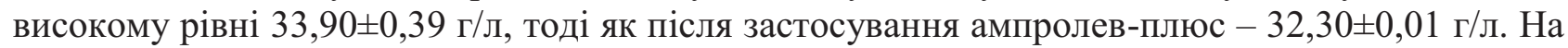
14 добу досліду глобуліни по першій групі зменшились на 2,4 \%, тоді як у другій групі на 7,7 \%, порівняно до контролю. Вже на 21 добу вміст загального глобуліну в першій групі склав

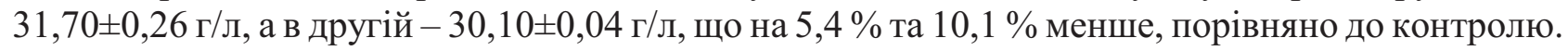

Стосовно глобулінових фракцій, то в першій дослідній групі вміст $\beta$-глобулінів ще на

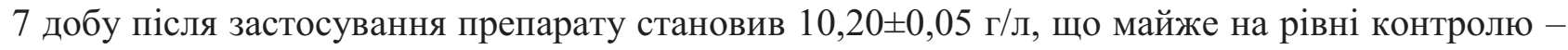




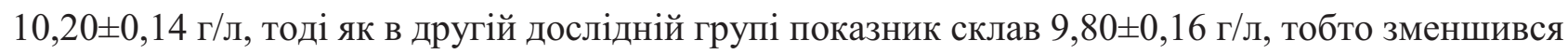
на 3,9%. В першій дослідній групі вірогідне зменшення на 3,9 \% відбулося лише на 14 добу.

Таблицяя 1

Біохімічні показники сироватки крові телят за змішаного перебігу криптоспоридіозу і еймеріозу після застосування бровітакокциду та ампролев-плюс (n=5, M $\pm \mathbf{m})$

\begin{tabular}{|c|c|c|c|c|}
\hline \multirow{2}{*}{ Показники } & \multirow{2}{*}{$\begin{array}{c}\text { Період } \\
\text { досліджень, діб }\end{array}$} & \multicolumn{3}{|c|}{ Групи } \\
\hline & & I дослідна & II дослідна & контрольна \\
\hline \multirow{5}{*}{ Загальний білок, г/л } & до застосування & $59,49 \pm 0,81^{*}$ & $58,24 \pm 0,46^{*}$ & $59,76 \pm 0,35$ \\
\hline & 3 & $58,98 \pm 0,24^{* *}$ & $57,85 \pm 0,55^{* *}$ & $59,91 \pm 0,16$ \\
\hline & 7 & $59,06 \pm 0,76^{*}$ & $58,62 \pm 0,47^{*}$ & $59,26 \pm 0,18$ \\
\hline & 14 & $60,24 \pm 1,01$ & $61,27 \pm 0,52$ & $59,78 \pm 0,05$ \\
\hline & 21 & $61,86 \pm 0,78$ & $62,98 \pm 0,22$ & $59,44 \pm 0,40$ \\
\hline \multirow{5}{*}{ Альбуміни, г/л } & до застосування & $25,28 \pm 0,98$ & $24,34 \pm 0,42^{* * *}$ & $26,26 \pm 0,06$ \\
\hline & 3 & $24,88 \pm 0,32^{*}$ & $24,35 \pm 0,45^{*}$ & $26,21 \pm 0,77$ \\
\hline & 7 & $25,16 \pm 0,24$ & $26,32 \pm 0,32^{*}$ & $25,76 \pm 0,56^{*}$ \\
\hline & 14 & $27,34 \pm 0,12$ & $30,17 \pm 0,21^{* * *}$ & $26,08 \pm 0,24^{* * *}$ \\
\hline & 21 & $30,16 \pm 0,12^{* * *}$ & $32,88 \pm 0,34^{* * *}$ & $25,94 \pm 0,12$ \\
\hline \multirow{5}{*}{ Глобуліни, г/л } & до застосування & $34,21 \pm 1,06^{*}$ & $33,90 \pm 0,91^{*}$ & $33,50 \pm 0,25$ \\
\hline & 3 & $34,10 \pm 0,41^{*}$ & $33,50 \pm 0,19^{*}$ & $33,70 \pm 0,22$ \\
\hline & 7 & $33,90 \pm 0,39$ & $32,30 \pm 0,01$ & $35,50 \pm 0,17$ \\
\hline & 14 & $32,90 \pm 0,02$ & $31,10 \pm 0,10$ & $33,70 \pm 0,16$ \\
\hline & 21 & $31,70 \pm 0,26$ & $30,10 \pm 0,14$ & $33,50 \pm 0,20$ \\
\hline \multirow{5}{*}{$\alpha$-глобуліни, г/л } & до застосування & $9,10 \pm 1,02^{*}$ & $9,90 \pm 0,36^{*}$ & $9,00 \pm 0,98$ \\
\hline & 3 & $9,10 \pm 0,85^{*}$ & $9,50 \pm 0,39^{*}$ & $9,20 \pm 0,76$ \\
\hline & 7 & $9,50 \pm 0,34$ & $9,0 \pm 0,29$ & $9,30 \pm 0,21$ \\
\hline & 14 & $9,20 \pm 0,21$ & $8,90 \pm 0,34$ & $9,50 \pm 0,52$ \\
\hline & 21 & $9,30 \pm 0,06$ & $8,80 \pm 0,35$ & $9,00 \pm 0,22$ \\
\hline \multirow{5}{*}{$\beta$-глобуліни, г/л } & до застосування & $10,30 \pm 0,92$ & $10,10 \pm 0,73$ & $10,30 \pm 0,02$ \\
\hline & 3 & $10,20 \pm 0,11$ & $10,20 \pm 0,43^{*}$ & $10,30 \pm 0,12$ \\
\hline & 7 & $10,20 \pm 0,05$ & $9,80 \pm 0,16^{*}$ & $10,20 \pm 0,14$ \\
\hline & 14 & $9,90 \pm 0,04^{*}$ & $9,10 \pm 0,13$ & $10,30 \pm 0,41$ \\
\hline & 21 & $8,90 \pm 0,05^{* * *}$ & $8,20 \pm 0,11$ & $10,40 \pm 0,09$ \\
\hline \multirow{5}{*}{$\gamma$-глобуліни, г/л } & до застосування & $14,80 \pm 0,63$ & $13,90 \pm 0,24$ & $14,20 \pm 0,18$ \\
\hline & 3 & $14,80 \pm 0,29$ & $13,80 \pm 0,15$ & $14,20 \pm 0,12$ \\
\hline & 7 & $14,20 \pm 0,10$ & $13,50 \pm 0,08$ & $14,0 \pm 0,11$ \\
\hline & 14 & $13,80 \pm 0,22$ & $13,10 \pm 0,18^{* *}$ & $13,90 \pm 0,09$ \\
\hline & 21 & $13,50 \pm 0,25$ & $13,10 \pm 0,16^{* * *}$ & $14,10 \pm 0,02$ \\
\hline \multirow{5}{*}{ A/Г коефіцієнт } & до застосування & 0,7 & 0,7 & 0,8 \\
\hline & 3 & 0,7 & 0,7 & 0,7 \\
\hline & 7 & 0,7 & 0,8 & 0,7 \\
\hline & 14 & 0,8 & 1,0 & 0,8 \\
\hline & 21 & 1,0 & 1,1 & 0,8 \\
\hline
\end{tabular}

Примітка: ${ }^{*}-\mathrm{p}<0,05,{ }^{* *}-\mathrm{p}<0,01,{ }^{* * *}-\mathrm{p}<0,01$ порівняно 3 контрольною групою

Після застосування бровітакокциду на 3 та 7 добу вміст $\gamma$-глобулінів становив

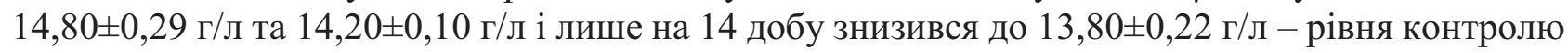

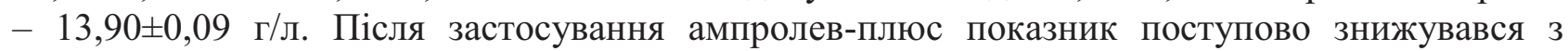

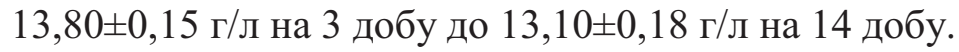

Співвідношення альбумінів до глобулінів сформувало відповідний А/Г коефіцієнт. В контрольній групі тварин протягом всього періоду досліджень, а також в дослідних групах до застосування препаратів він становив 0,7-0,8. Після застосування бровітакокциду А/Г коефіцієнт склав 1,0 лише на 21 добу досліду, тоді як при застосуванні ампролев-плюс - вже на 14 добу. 
У інвазованих телят як дослідних, так і контрольної групи, реєстрували високу

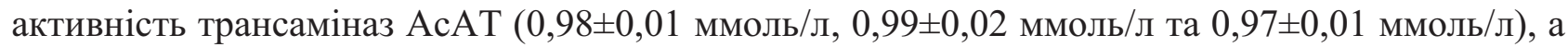

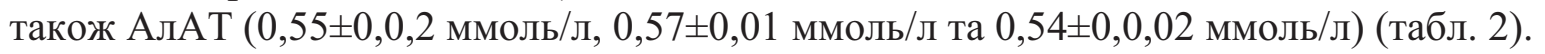

Таблиця 2

Імунологічні показники сироватки крові телят за змішаного перебігу криптоспоридіозу і еймеріозу після застосування бровітакокциду та ампролев-плюс (n=5, M \pm m)

\begin{tabular}{|c|c|c|c|c|}
\hline \multirow{5}{*}{ АлАТ, ммоль/л } & до застосування & $0,55 \pm 0,02$ & $0,57 \pm 0,01$ & $0,54 \pm 0,02$ \\
\hline & 3 & $0,57 \pm 0,02$ & $0,59 \pm 0,03$ & $0,55 \pm 0,01$ \\
\hline & 7 & $0,54 \pm 0,01$ & $0,52 \pm 0,02$ & $0,54 \pm 0,02$ \\
\hline & 14 & $0,50 \pm 0,02$ & $0,46 \pm 0,01^{* *}$ & $0,56 \pm 0,03$ \\
\hline & 21 & $0,43 \pm 0,01^{* * *}$ & $0,42 \pm 0,01^{* * *}$ & $0,56 \pm 0,02$ \\
\hline \multirow{5}{*}{ АсАТ, ммоль/л } & до застосування & $0,98 \pm 0,01$ & $0,99 \pm 0,02$ & $0,97 \pm 0,01$ \\
\hline & 3 & $0,96 \pm 0,02$ & $0,98 \pm 0,03$ & $0,97 \pm 0,01$ \\
\hline & 7 & $0,92 \pm 0,01$ & $0,91 \pm 0,04^{*}$ & $0,99 \pm 0,02$ \\
\hline & 14 & $0,90 \pm 0,02^{*}$ & $0,87 \pm 0,01^{* * *}$ & $0,98 \pm 0,02$ \\
\hline & 21 & $0,88 \pm 0,01^{* * *}$ & $0,87 \pm 0,02$ & $0,98 \pm 0,02$ \\
\hline \multirow{5}{*}{ ЦІК, мг/мл } & до застосування & $76,49 \pm 2,05$ & $77,11 \pm 0,92$ & $75,98 \pm 1,16$ \\
\hline & 3 & $77,14 \pm 1,01$ & $76,11 \pm 2,01$ & $76,35 \pm 1,04$ \\
\hline & 7 & $76,98 \pm 0,02$ & $70,24 \pm 0,90$ & $75,96 \pm 1,02$ \\
\hline & 14 & $66,34 \pm 0,90$ & $65,12 \pm 0,18^{* * *}$ & $76,07 \pm 1,16$ \\
\hline & 21 & $61,92 \pm 1,02^{* * *}$ & $61,09 \pm 0,07^{* * *}$ & $75,34 \pm 0,86$ \\
\hline \multirow{5}{*}{ Серомукоїди, мг/мл } & до застосування & $0,19 \pm 0,02$ & $0,18 \pm 0,01$ & $0,18 \pm 0,01$ \\
\hline & 3 & $0,19 \pm 0,02$ & $0,18 \pm 0,01$ & $0,18 \pm 0,01$ \\
\hline & 7 & $0,18 \pm 0,01$ & $0,16 \pm 0,02$ & $0,19 \pm 0,02$ \\
\hline & 14 & $0,16 \pm 0,02^{*}$ & $0,14 \pm 0,01^{*}$ & $0,19 \pm 0,02$ \\
\hline & 21 & $0,14 \pm 0,01^{*}$ & $0,12 \pm 0,02^{*}$ & $0,18 \pm 0,01$ \\
\hline
\end{tabular}

Примітка: ${ }^{*}-\mathrm{p}<0,05,{ }^{* *}-\mathrm{p}<0,01,{ }^{* * *}-\mathrm{p}<0,01$ порівняно 3 контрольною групою

При застосуванні бровітакокциду активність АсАТ істотно зменшилась на 10,2 \% лише на 21 добу, тоді як при застосуванні апмпролев-плюс зменшення відбулося вже на 14 добу на $11,2 \%$, порівняно до контролю.

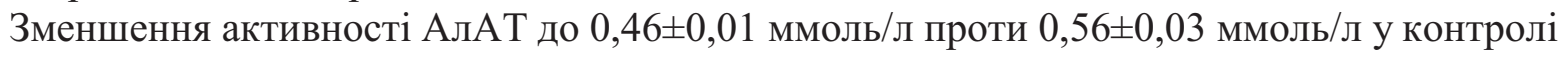
реєстрували в другій дослідній групі тварин на 14 добу, тоді як в першій групі - лише на 21 добу $(0,43 \pm 0,01$ ммоль/л).

Концентрація циркулюючих імунних комплексів на 7 добу досліду у другій групі тварин суттєво зменшилась на 7,5 \%, тоді як в першій групі зменшення ЦІК на 12,8 \% реєстрували лише на 14 добу досліду, що свідчить про зменшення імуносупресії препаратів.

3 перебігом інвазії у всіх групах тварин реєстрували високу концентрацію серомукоїдів в межах 0,18 $\pm 0,01-0,19 \pm 0,02$ мг/мл. Після застосування препаратів у першій дослідній групі на 7 добу концентрація серомукоїдів знизилась на 5,3 \%, а по другій групі - на 15,8 \%. Зменшення показника концентрації серомукоїдів на 15,8 \% по першій дослідній групі реєстрували лише на 14 добу.

Отже, у біохімічному складі крові телят після застосування еймеріостатиків відмічалося активне відновлення вмісту загального білка, підвищувався вміст альбумінів на фоні зменшення загальних глобулінів. Активність ферментів наблизилась до фізіологічної межі. Концентрація циркулюючих імунних комплексів у сироватці крові телят протягом періоду спостереження знижувалася, що свідчило про відновлення організму після токсичного впливу криптоспоридій та еймерій. Концентрація серомукоїдів у сироватці крові телят знижувалася, що підтверджувало ефективність лікування. 


\title{
В И С Н О В К И
}

1. У сироватці крові телят за змішаного перебігу криптоспоридіозу та еймеріозу на 14 добу після застосування бровітакокциду і ампролеву-плюс вміст альбумінів збільшився на 4,8 та 15,7 \%, відповідно, тоді як глобуліни зменшилися на 2,4 та 7,7 \%.

2. Бровітакокцид діяв імуносупресивно упродовж 21 доби, тоді як ампролев-плюс упродовж 14 діб. Нормалізувався вміст загального білку, альбумінів і глобулінів, що стало основою формування А/Г коефіцієнту та активності ферментів АлАТ і АсАТ, циркулюючих імунних комплексів, серомукоїдів.

Перспективи досліджень. Планується з’ясувати вплив ампролеву-плюс у поєднанні 3 пробіотиком на біохімічні та імунологічні показник сироватки крові за криптоспоридіозу та еймеріозу телят.

\section{EFFECT OF EIMEROSTATS ON BIOCHEMICAL AND IMMUNOLOGICAL INDICES OF CALVES' BLOOD SERUM DURING A MIXED COURSE OF CRYPTOSPORIDIOSIS AND EIMERIOSIS}

\author{
V.V. Skalchuk ${ }^{1}$, M. V. Bogach ${ }^{2}$ I. V. Pivovarova ${ }^{1}$ \\ ${ }^{1}$ Odessa State Agrarian University \\ 13, Panteleimonivska str., Odessa, 65039, Ukraine \\ ${ }^{2}$ Odessa Experimental Station of NSC "Institute of Experimental and Clinical Veterinary Medicine" \\ 2, Svobody Str., Odessa, 65037, Ukraine
}

\section{S U M M A R Y}

Cryptosporidia often parasitize in combination with eimeria and helminths, which leads to a complication of therapeutic treatment measures and to an increase in the level of death among young animals. The scheme of application of medical preparations for animals, which would have high efficiency, remains uncertain. The developed medicinal product "Amprolev-plus" exhibited 100\% extensive efficiency for cryptosporidiosis and $95.7 \%$ for eimeria. Therefore, the relevant issue is still as follows: investigation into the influence of eimerostats on biochemical and immunological indices of calves' blood serum in the mixed invasion course.

Within the experiment, 3 days after applying Brovitakoktsid and Amprelev-plus, the total protein content decreased by $0.9 \%$ and $0.7 \%$ and albumin by $5.1 \%$ and $7.1 \%$, respectively, compared with the control group.

After applying Brovitakoktsid, content of $\beta$-globulins on the $7^{\text {th }}$ day was $10,20 \pm 0,05 \mathrm{~g} / \mathrm{L}$, which is almost at the control level of $10.20 \pm 0,14 \mathrm{~g} / \mathrm{L}$, whereas indicators after applying Amprolevplus were at the level of $9.80 \pm 0.16 \mathrm{~g} / \mathrm{L}$, i.e., decreased by $3.9 \%$.

After applying Brovitakoktsid on the $3^{\text {rd }}$ and $7^{\text {th }}$ day, the content of $\gamma$-globulins made up of $14.80 \pm 0,29 \mathrm{~g} / \mathrm{L}$ and $14.20 \pm 0,10 \mathrm{~g} / \mathrm{L}$, and the indicator decreased only on the $14^{\text {th }}$ day to $13.80 \pm 0.22$ $\mathrm{g} / \mathrm{L}$, that is almost the control level of $13.90 \pm 0.09 \mathrm{~g} / \mathrm{L}$. After applying Amprolev-plus, the indicator gradually decreased from $13.80 \pm 0.15 \mathrm{~g} / \mathrm{L}$ on the $3^{\text {rd }}$ day up to $13.10 \pm 0.18 \mathrm{~g} / \mathrm{L}$ on the $14^{\text {th }}$ day.

Albumin/Globulin ratio formed the corresponding $\mathrm{A} / \mathrm{G}$ coefficient. It was at the level of $0.7-0.8$ in the control group of animals during the entire period of research, as well as in research groups before applying drugs. After applying Brovitakoktsid, the $\mathrm{A} / \mathrm{G}$ ratio made 1.0 only on the $21^{\text {st }}$ day of the experiment, whereas after Amprolev-plus application the same ratio was obtained already on the $14^{\text {th }}$ day.

High activity of AST and ALT transaminases was recorded in the invasive calves of both experimental and control groups. The AST activity significantly decreased by $10.2 \%$ only on the $21^{\text {st }}$ 
day after Brovitakoktsid application, whereas the decrease by $11.2 \%$ was observed after Amprolevplus application on the $14^{\text {th }}$ day, compared to the control.

The concentration of circulating immune complexes (CIC) on the $7^{\text {th }}$ day of the experiment in the second group of animals significantly decreased by $7.5 \%$, while in the first group the CIC concentration decrease by $12.8 \%$ was recorded only on the $14^{\text {th }}$ day of the experiment, which indicates a reduction in the immunosuppression of preparations.

Keywords: CRYPTOSPORIDIOSIS, EIMERIOSIS, CALVES, BIOCHEMICAL PARAMETERS OF SERUM OF BLOOD.

\title{
ВЛИЯНИЕ ЭЙМЕРИОСТАТИКОВ НА БИОХИМИЧЕСКИЕ И ИММУНОЛОГИЧЕСКИЕ ПОКАЗАТЕЛИ СЫВОРОТКИ КРОВИ ТЕЛЯТ ПРИ СМЕШАННОМ ТЕЧЕНИИ КРИПТОСПОРИДИОЗА И ЭЙМЕРИОЗА
}

\author{
В. В. Скальчук ${ }^{1}$, Н. В. Богач ${ }^{2}$ И. В. Пивоварова \\ ${ }^{1}$ Одесский государственный аграрный университет \\ ул. Пантелеймоновская, 13, г. Одесса 65039, Украина \\ ${ }^{2}$ Одесская опытная станция ННЦ «Институт экспериментальной и клинической \\ ветеринарной медицины» \\ пр-кт Свободы, 2, г. Одесса, 65037, Украина
}

\section{А Н Н О Т А ЦИ Я}

В статье приведены данные о влиянии эймериостатиков на биохимические и иммунологические показатели сыворотки крови телят при смешанном течении криптоспоридиоза и эймериоза. Установлено, что в сыворотке крови телят на 14 сутки после применения бровитакокцида и ампролева-плюс увеличилось содержание альбуминов на 4,8 \% и 15,7 \% соответственно, тогда как глобулины уменьшились на 2,4 \% и 7,7 \%.

Восстановление содержания общего белка, альбуминов и глобулинов, что стало основой формирования $\mathrm{A} / \Gamma$ коэффициента было отмечено уже на 14 сутки после задавания ампролев-плюс, а в течении всего эксперимента наблюдалась тенденция к уменьшению активности ферментов АлАТ и АсАТ и концентрации циркулирующих иммунных комплексов, серомукоидов, что свидетельствует о незначительном, по сравнению с бровитакокцидом, иммуносупрессивном действии препарата.

Ключевые слова: КРИПТОСПОРИДИОЗ, БИОХИМИЧЕСКИЕ ПОКАЗАТЕЛИ СЫВОРОТКИ КРОВИ.

ЭЙМЕРИОЗ, ТЕЛЯТА,

\section{Л I T E P A T Y P A}

1. Апатенко B. М. Паразитоценозы как неизбежная реальность в инфекционной патологии / В. М. Апатенко // Ветеринарна медицина. - 2002. - Вип. 80. - С. 671-673.

2. Журенко B. В. Вплив збудника криптоспоридіозу телят на біохімічні показники сироватки крові / В. В. Журенко // Науковий вісник ЛНУВМ та БТ імені С. З. Гжицького. 2016. - Т. 18. - № 3 (70). - С. 100-102.

3. Журенко B. В. Криптоспоридіоз великої рогатої худоби (поширення, діагностика та заходи боротьби) автореф. дис. ... канд. вет. наук : 16.00.11 / В. В. Журенко; Нац. ун-т біоресурсів і природокористування України. - Київ, 2016. - 21 с.

4. Слободян Р. О. Еймеріоз телят (поширення, діагностика та лікування): автореф. дис. ... канд. вет. наук : 16.00.11 / Р. О. Слободян; Нац. ун-т біоресурсів і природокористування України. - Київ, 2016. - 23 с. 
5. Патент на корисну модель № 119843 Україна, МПК А 61К 31/00. Препарат для лікування еймеріозу та криптоспоридіозу тварин «Ампролев-плюс» / М. В Богач, Б. Т. Стегній, Л. В. Бондаренко, В. В. Скальчук; заявник та правовласник Нац. наук. центр «Інт експерим. і клініч. вет. медицини». - № u 2017 04014; заявл. 24.04.2017; опубл. 10.10.2017, Бюл. № 19. -4 c.

6. Скальчук B. B. Порівняльна оцінка ефективності бровітакокциду та засобу «Ампроев-плюс» за змішаного перебігу криптоспоридіозу та еймеріозу телят // В. В. Скальчук, М. В. Богач // Вісник Сумського НАУ. - Суми, 2018. - Вип. 1 (42). - С. 133-135.

7. М. В. Богач Визначення параметрів гострої токсичності препарату «Ампроев-плюс» на білих мишах / М. В. Богач, Л. В. Бондаренко, В. В. Скальчук // Науково-технічний бюлетень ДНДКІ ветпрепаратів та кормових добавок і Інституту біології тварин. - Львів, 2017. - Вип. 18. - № 2. - С. 281-285.

\section{References}

1. Apatenko V. M. Parazitocenozy kak neizbezhnaja real'nost' v infekcionnoj patologii / V. M. Apatenko // Veterinarna medicina. - 2002. - Vip. 80. - S. 671-673. (in Ukrainian)

2. Zhurenko V. V. Vpliv zbudnika kriptosporidiozu teljat na biohimichni pokazniki sirovatki krovi / V. V. Zhurenko // Naukovij visnik LNUVM ta BT imeni S. Z. Gzhic'kogo. - 2016. - T. 18. № 3 (70). - S. 100-102. (in Ukrainian)

3. Zhurenko V. V. Kriptosporidioz velikoï rogatoï hudobi (poshirennja, diagnostika ta zahodi borot'bi) avtoref. dis. ... kand. vet. nauk : 16.00.11 / V. V. Zhurenko; Nac. un-t bioresursiv i prirodokoristuvannja Ukraïni. - Kiïv, 2016. - 21 s. (in Ukrainian)

4. Slobodjan R. O. Ejmerioz teljat (poshirennja, diagnostika ta likuvannja): avtoref. dis. ... kand. vet. nauk : 16.00.11 / R. O. Slobodjan; Nac. Un-t bioresursiv i prirodokoristuvannja Ukrainy. - Kiïv, 2016. - 23 s. (in Ukrainian)

5. Patent na korisnu model' № 119843 Ukraïna, MPK A 61K 31/00. Preparat dlja likuvannja ejmeriozu ta kriptosporidiozu tvarin «Amprolev-pljus»/ M. V Bogach, B. T. Stegnij, L. V. Bondarenko, V. V. Skal'chuk; zajavnik ta pravovlasnik Nac. nauk. centr «In-t eksperim. i klinich. vet. medicini». - № u 2017 04014; zajavl. 24.04.2017; opubl. 10.10.2017, Bjul. № 19. - 4 s. (in Ukrainian)

6. Skal'chuk V. V. Porivnjal'na ocinka efektivnosti brovitakokcidu ta zasobu «Amproevpljus» za zmishanogo perebigu kriptosporidiozu ta ejmeriozu teljat // V. V. Skal'chuk, M. V. Bogach // Visnik Sums'kogo NAU. - Sumi, 2018. - Vip. 1 (42). - S. 133-135. (in Ukrainian)

7. M. V. Bogach Viznachennja parametriv gostroï toksichnosti preparatu «Amproev-pljus» na bilih mishah / M. V. Bogach, L. V. Bondarenko, V. V. Skal'chuk // Naukovo-tehnichnij bjuleten' DNDKI vetpreparativ ta kormovih dobavok i Institutu biologiï tvarin. - L'viv, 2017. - Vip. 18. - № 2. - S. 281-285. (in Ukrainian)

Рецензент - I. І. Панікар, д. вет. н., професор, ОДАУ. 